\title{
2,3-Dihydroxypropane-1-sulfonate degraded by Cupriavidus pinatubonensis JMP134: purification of dihydroxypropanesulfonate 3-dehydrogenase
}

\author{
Correspondence \\ Alasdair M. Cook \\ alasdair.cook@uni-konstanz.de
}

Received 23 December 2009

Revised 3 February 2010

Accepted 7 February 2010

\author{
Jutta Mayer, ${ }^{1}$ Thomas Huhn, ${ }^{2}$ Michael Habeck, ${ }^{1}$ Karin Denger, ${ }^{1}$ \\ Klaus Hollemeyer ${ }^{3}$ and Alasdair M. Cook ${ }^{1}$ \\ ${ }^{1}$ Department of Biology, The University, D-78457 Konstanz, Germany \\ ${ }^{2}$ Department of Chemistry, The University, D-78457 Konstanz, Germany \\ ${ }^{3}$ Institute of Biochemical Engineering, University of the Saarland, D-66041 Saarbrücken, Germany
}

\begin{abstract}
2,3-Dihydroxypropane-1-sulfonate (DHPS) is a widespread intermediate in plant and algal transformations of sulfoquinovose (SQ) from the plant sulfolipid sulfoquinovosyl diacylglycerol. Further, DHPS is recovered quantitatively during bacterial degradation of SQ by Klebsiella sp. strain ABR11. DHPS is also a putative precursor of sulfolactate in e.g. Ruegeria pomeroyi DSS-3. A bioinformatic approach indicated that some 28 organisms with sequenced genomes might degrade DHPS inducibly via sulfolactate, with three different desulfonative enzymes involved in its degradation in different organisms. The hypothesis for Cupriavidus pinatubonensis JMP134 (formerly Ralstonia eutropha) involved a seven-gene cluster (Reut_C6093-C6087) comprising a Lacl-type transcriptional regulator, $\mathrm{HpsR}$, a major facilitator superfamily uptake system, $\mathrm{HpsU}$, three $\mathrm{NAD}(\mathrm{P})^{+}$-coupled DHPS dehydrogenases, HpsNOP, and $(R)$-sulfolactate sulfo-lyase (SuyAB) [EC 4.4.1.24]. HpsOP effected a DHPS-racemase activity, and HpsN oxidized ( $R$ )DHPS to $(R)$-sulfolactate. The hypothesis for Roseovarius nubinhibens ISM was similar, but involved a tripartite ATP-independent transport system for DHPS, HpsKLM, and two different desulfonative enzymes, (S)-cysteate sulfo-lyase [EC 4.4.1.25] and sulfoacetaldehyde acetyltransferase (Xsc) [EC 2.3.3.15]. Representative organisms were found to grow with DHPS and release sulfate. C. pinatubonensis JMP134 was found to express at least one NAD(P) ${ }^{+}$ coupled DHPS dehydrogenase inducibly, and three different peaks of activity were separated by anion-exchange chromatography. Protein bands (SDS-PAGE) were subjected to peptide-mass fingerprinting, which identified the corresponding genes (hpsNOP). Purified HpsN converted DHPS to sulfolactate. Reverse-transcription PCR confirmed that $h p s N O U P$ were transcribed inducibly in strain JMP134, and that $h p s K L M$ and $h p s N O P$ were transcribed in strain ISM. DHPS degradation is widespread and diverse, implying that DHPS is common in marine and terrestrial environments.
\end{abstract}

\section{INTRODUCTION}

2,3-Dihydroxy-1-propanesulfonate (DHPS; sulfopropanediol) advanced from a hypothetical intermediate (Benson

Abbreviations: ComDE, sulfopyruvate decarboxylase [EC 4.1.1.79]; CuyA, (S)-cysteate sulfo-lyase [EC 4.4.1.25]; DHPS, 2,3-dihydroxypropane-1-sulfonate; HpsKLM, TRAP-T transporter for DHPS; HpsO and HpsP, DHPS 2-dehydrogenases of opposite stereochemistry; HpsN, DHPS 3-dehydrogenase (sulfolactate forming); HpsU, DHPS uptake; SIcD, sulfolactate dehydrogenase; $S Q$, sulfoquinovose; SuyAB, sulfolactate sulfo-lyase [EC 4.4.1.24]; Xsc, sulfoacetaldehyde acetyltransferase [EC 2.3.3.15].

Supplementary material, with details of the chemical synthesis of $(R, S)$ DHPS, bacteria with hps genes, and RT-PCR primers, is available with the online version of this paper.
\& Shibuya, 1961), to a tentatively identified intermediate (Shibuya et al., 1963), to an identified intermediate (Busby, 1966), to a widespread plant intermediate (Lee \& Benson, 1972) and an excretion product of all diatoms (Benson \& Lee, 1972). The source of this intermediate is sulfoquinovose (SQ; 6-deoxy-6-sulfoglucose), the headgroup of the plant sulfolipid sulfoquinovosyl diacylglycerol (e.g. Benson, 1963), in a process termed sulfoglycolysis (Benson \& Shibuya, 1961). DHPS is also an intermediate in the bacterial degradation of SQ, whereby Klebsiella sp. strain ABR11 initially excretes DHPS quantitatively (Roy et al., 2003). The fate of DHPS after prolonged incubation was partly sulfolactate, partly sulfate and largely unknown, but working with the name 'sulfoglycolysis', a logical pathway of SQ degradation was hypothesized (Roy et al., 2003). 
Work on the degradation of $(R, S)$-3-sulfolactate has yielded four degradative pathways involving three desulfonation reactions: $(R)$-sulfolactate sulfo-lyase (SuyAB) [EC 4.4.1.24] (Denger \& Cook, 2010; Rein et al., 2005), (S)cysteate sulfo-lyase (CuyA) [EC 4.4.1.25] (Denger et al., 2006) and sulfoacetaldehyde acetyltransferase (Xsc) [EC 2.3.3.15] (Denger et al., 2009; Ruff et al., 2003). The pathways are: (i) oxidation to sulfopyruvate and transamination to allow desulfonation by CuyA (Denger et al., 2009), (ii) oxidation to sulfopyruvate and decarboxylation to allow desulfonation by Xsc - both (i) and (ii) are branches of the bifurcated sulfolactate degradative pathway identified in Roseovarius nubinhibens ISM (Denger et al., 2009), (iii) direct desulfonation via SuyAB in Paracoccus pantotrophus, whereby the racemase is unknown (Denger et al., 2009; Rein et al., 2005), and (iv) the function of two sulfolactate dehydrogenases (ComC and SlcC) of opposite stereochemistry to generate the substrate for SuyAB in Chromohalobacter salexigens (Denger \& Cook, 2010).

The work on the degradation of $(R, S)$-3-sulfolactate in Roseovarius nubinhibens ISM and other organisms led us to suspect that a widespread gene cluster (Fig. 1b) encoded inducible enzymes for the uptake of DHPS and its conversion to sulfolactate (Denger et al., 2009). We thus hypothesize (Fig. 1a, b) that a tripartite ATP-independent transport system (TRAP-T) [TC 2.A.56.-.-] pumps DHPS into the cell, where two dehydrogenases are responsible for conversion to the correct DHPS enantiomer, whose primary alcohol is subject to oxidation to $(2 R)$-sulfolactate via a third dehydrogenase. The sulfolactate is then desulfonated via the characterized bifurcated pathway (Denger et al., 2009).

We now present evidence, including enzyme purification, to support the pathway (Fig. 1a), with different transporters and desulfonative enzymes, in Roseovarius nubinhibens ISM and Cupriavidus pinatubonensis JMP134 (formerly Ralstonia eutropha). Further, there are indications of biodiversity in transport systems in other organisms.

\section{METHODS}

Chemical synthesis of DHPS and the sources of other chemicals. The two-step synthesis of $(R, S)$-DHPS (sodium salt) $\left[\mathrm{CH}_{2}(\mathrm{OH})-\mathrm{CH}(\mathrm{OH})-\mathrm{CH}_{2}-\mathrm{SO}_{3} \mathrm{Na}\right]$ via barium bispropane-2,3-diolsulfonate $\left(\left[\mathrm{CH}_{2}(\mathrm{OH})-\mathrm{CH}(\mathrm{OH})-\mathrm{CH}_{2}-\mathrm{SO}_{3}^{-}\right]_{2} \mathrm{Ba}^{2+}\right)$ from allylic alcohol $\left(\mathrm{CH}_{2}=\mathrm{CH}-\mathrm{CH}_{2} \mathrm{OH}\right)$ is based on an old procedure described in old-fashioned German (Friese, 1938). The method, which has a $79 \%$ yield and takes about 2 days with modern apparatus, is described in English in the supplementary material available with the online version of this paper. NMR data confirming the synthesis of highquality DHPS are shown in Fig. 2.

Racemic sulfolactate was synthesized as described elsewhere (Roy et al., 2003), as was the bisulfite addition complex of sulfoacetaldehyde (Denger et al., 2001). Commercial chemicals were of the highest purity available from Sigma-Aldrich, Fluka, Roth, Merck or Biomol. Taq DNA polymerase, Moloney murine leukaemia virus reverse transcriptase and RNase-free DNase were from Fermentas. The E.Z.N.A. bacterial RNA kit (Omega Bio-Tek) was used for RNA preparation. Oligonucleotides were synthesized by Microsynth (Balgach, Switzerland).

Organisms and growth media. Cupriavidus pinatubonensis JMP134 (DSM 4058; formerly Ralstonia eutropha) was grown in a phosphatebuffered mineral salts medium, pH 7.2 (Thurnheer et al., 1986). The marine organisms Hoeflea phototrophica DFL-43 (DSM 17068) (Biebl et al., 2006), Roseobacter denitrificans OCh 114 (DSM 7001) (Shiba, 1991), Roseovarius nubinhibens ISM (DSM 15170) and Ruegeria pomeroyi DSS-3 (DSM 15171) (González et al., 2003) were cultured in modified Silicibacter basal medium (Denger et al., 2006). A supplement of yeast extract was required by strains DFL-43 (0.01\%), OCh 114 and ISM (0.05\%) (Denger et al., 2009). Roseobacter sp. strain MED193 (J. Pinhassi, University of Kalmar, Sweden) and Roseovarius sp. strain 217 (Schäfer et al., 2005) were grown in Tris-buffered artificial seawater (Krejčík et al., 2008) with vitamins (Pfennig, 1978). All strains were grown aerobically at $30{ }^{\circ} \mathrm{C}$, with the exception of strain MED193, which was grown at $25^{\circ} \mathrm{C}$. Either $10 \mathrm{mM}$ DHPS or $15 \mathrm{mM}$ acetate was added to the appropriate medium as sole source of carbon and energy. Either $20 \mathrm{mM}$ or $10 \mathrm{mM}$ (for marine organisms) ammonium chloride was used as nitrogen source. Precultures $(3 \mathrm{ml})$ were grown in $30 \mathrm{ml}$ screw-cap tubes in a roller. Cultures for enzyme assays and for protein separations were grown, harvested at an optical density at $580 \mathrm{~nm}$ $\left(\mathrm{OD}_{580}\right)$ of 0.6-0.8, washed and disrupted in a French pressure cell as described previously (Mayer \& Cook, 2009). Cultures for total RNA preparation were harvested in the early exponential growth phase at $\mathrm{OD}_{580}$ values of about 0.3 (C. pinatubonensis JMP134) or about $0.46-$ 0.49 (Roseovarius nubinhibens ISM).

Analytical methods. Growth was followed as $\mathrm{OD}_{580}$. Sulfate was quantified turbidimetrically as a suspension of $\mathrm{BaSO}_{4}$ (Sörbo, 1987), sulfite as the fuchsin adduct (Denger et al., 2001). Acetyl phosphate was determined as iron(III) acetyl hydroxamate (Racker, 1962). Sulfolactate was quantified by ion chromatography with suppression (Denger et al., 2004). Matrix-assisted laser-desorption ionization time-of-flight mass spectrometry (MALDI-TOF-MS) in the negativeion mode was used to confirm the identity of sulfolactate formed in the reaction of HpsN with DHPS (Tholey et al., 2002). Denatured proteins were separated on $13 \%$ SDS-PAGE gels and stained with Coomassie brilliant blue R250 (Laemmli, 1970). Quantification of protein bands was done using the Gel Doc XR gel documentation system (Bio-Rad). Peptide mass fingerprint analyses were done by the proteomics facility of the University of Konstanz.

RT-PCR experiments were done as described previously (Krejč́k et al., 2008), with the primers listed in Supplementary Table S2. Before reverse transcription, RNA preparations were tested for residual DNA using primer pairs JMP-hpsN-f/r for C. pinatubonensis, and ISM-hpsN-f/r for Roseovarius nubinhibens ISM. Chromosomal DNA of strains JMP134 and ISM, which was used in PCR positive controls, was isolated as described elsewhere (Desomer et al., 1991). PCR products were visualized on $1.5 \%$ agarose gels.

Enzyme assays. Activity of DHPS dehydrogenases was assayed photometrically $(340 \mathrm{~nm})$ at $30{ }^{\circ} \mathrm{C}$ as the formation of $\mathrm{NAD}(\mathrm{P}) \mathrm{H}$. The reaction mixture contained $10 \mathrm{mM}$ DHPS, $4 \mathrm{mM} \mathrm{NAD}(\mathrm{P})^{+}$and $1-200 \mu \mathrm{g}$ protein $\mathrm{ml}^{-1}$ in $50 \mathrm{mM}$ Tris/ $\mathrm{HCl}, \mathrm{pH}$ 9.0. In addition, activity of the sulfolactate-forming DHPS 3-dehydrogenase was measured discontinuously by quantification of sulfolactate (ion chromatography). Samples $(20 \mu \mathrm{l})$ taken from the enzyme reaction were injected directly on to the ion chromatographic column, where the eluent at $\mathrm{pH} 11$ stopped the reaction. The use of hydrazine (0.1$0.4 \mathrm{M})$ in order to increase the activity of the $\mathrm{NAD}^{+}$-coupled DHPS 2-dehydrogenase HpsP had no significant effects. Kinetic constants were determined with reaction mixtures containing various DHPS concentrations and $4 \mathrm{mM} \mathrm{NAD}^{+}$, or with various $\mathrm{NAD}^{+}$concen- 
(a)

(S)-DHPS

(R)-DHPS

$\overbrace{\mathrm{OH}}^{\mathrm{SO}_{3}}{ }^{-}$

$\overbrace{\text { 总 }} \mathrm{SO}_{3}$

(1)
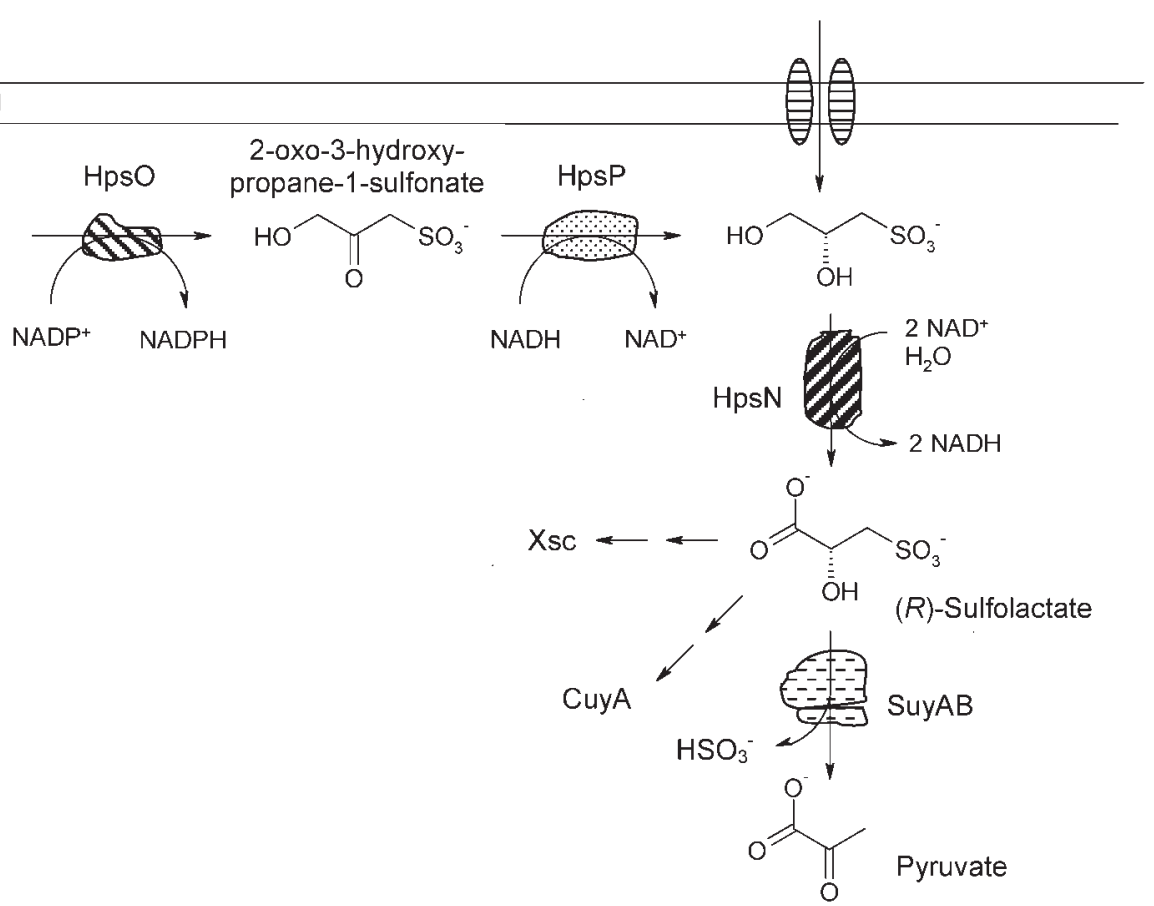

(b)

C. pinatubonensis JMP134

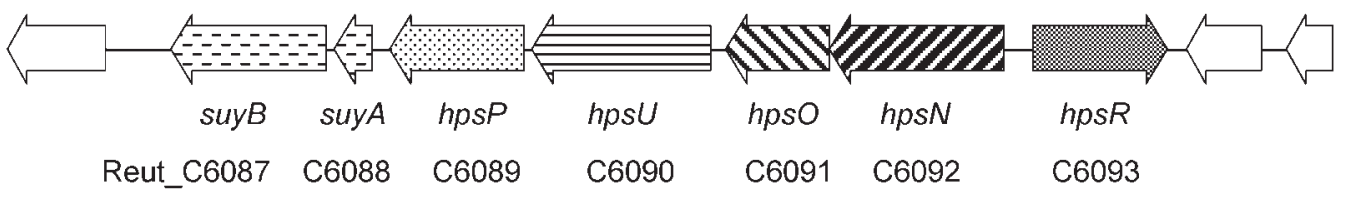

R. nubinhibens ISM
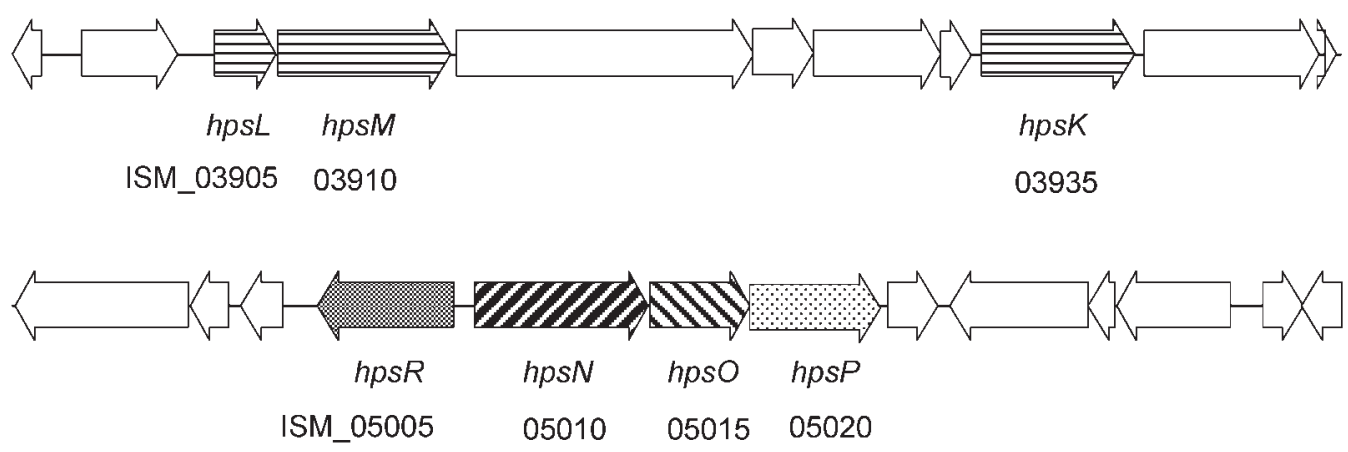

Fig. 1. (a) The conversion of DHPS to $(R)$-sulfolactate and the three possible desulfonation reactions found in different organisms; (b) gene clusters encoding the relevant enzymes in C. pinatubonensis JMP134 and Roseovarius nubinhibens ISM, with locus tags and our annotations. 


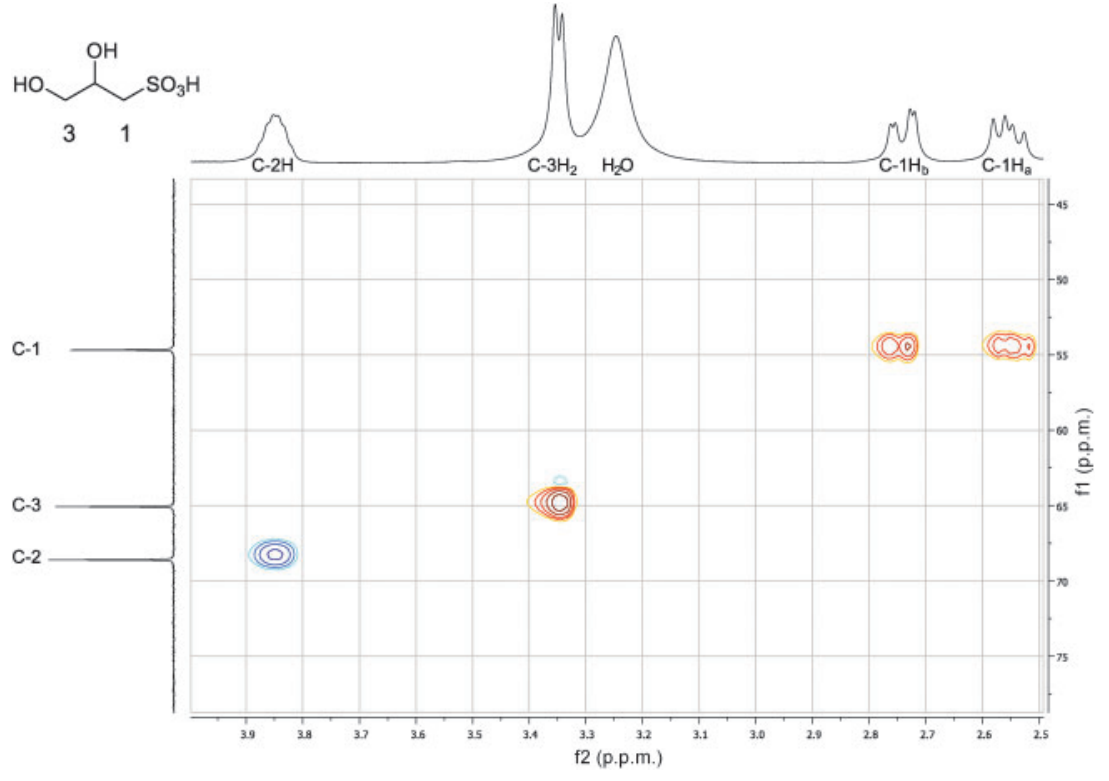

Fig. 2. Heteronuclear single-quantum coherence-NMR spectrum of DHPS (free acid) ( $\left.D_{6}-\mathrm{DMSO}\right)$. trations and $10 \mathrm{mM}$ DHPS. The $\mathrm{pH}$ optimum of $\mathrm{HpsN}$ was determined in a buffer system with constant ionic strength, composed of $\mathrm{N}$-(2-acetamido)-2-aminoethanesulfonate, Tris and ethanolamine (Ellis \& Morrison, 1982). Sulfolactate sulfo-lyase (SuyAB, EC 4.4.1.24) and (S)-cysteate sulfo-lyase (CuyA, EC 4.4.1.25) were assayed as release of sulfite from sulfolactate (SuyAB) (Rein et al., 2005) or from (S)-cysteate (CuyA), respectively (Denger et al., 2006). Sulfoacetaldehyde acetyltransferase (Xsc, EC 2.3.3.15) was assayed as the formation of acetyl phosphate or sulfite from sulfoacetaldehyde (Ruff et al., 2003).

Protein separations. The membrane/particulate fraction was removed from the crude extract by ultracentrifugation $(170000 \mathrm{~g}$ for $30 \mathrm{~min}$ at $4{ }^{\circ} \mathrm{C}$ ). The supernatant fluid was designated the soluble fraction, which was subject to anion-exchange chromatography (Mono Q HR 10/10; Pharmacia). A three-step gradient of sodium sulfate $(0-75 \mathrm{mM}$ in $10 \mathrm{~min}$ followed by $75-150 \mathrm{mM}$ in $45 \mathrm{~min}$ and $150-500 \mathrm{mM}$ in $10 \mathrm{~min}$ ) in $50 \mathrm{mM}$ potassium phosphate buffer ( $\mathrm{pH}$ 7.2) was applied at a flow rate of $1 \mathrm{ml}$ $\min ^{-1}$. Three DHPS dehydrogenase activities were eluted. Activity of SuyAB was detected in fractions which eluted at $100 \mathrm{mM}$ sodium sulfate. Active fractions of $\mathrm{HpsN}$ were pooled and brought to $1.7 \mathrm{M}$ ammonium sulfate, the precipitate was spun off, and the supernatant was subjected to hydrophobic interaction chromatography (Phenyl Superose HR 10/10; Pharmacia). In a linear decreasing gradient of ammonium sulfate in $20 \mathrm{mM}$ potassium phosphate buffer ( $\mathrm{pH} 7.2$ ), HpsN eluted after the end of the gradient at $0 \mathrm{mM}$ ammonium sulfate. The rebuffered and concentrated active fraction was loaded on to a gel filtration column (Superose 12 HR 10/30; Pharmacia) in $20 \mathrm{mM}$ potassium phosphate buffer ( $\mathrm{pH} 7.2$ ) with $150 \mathrm{mM}$ sodium

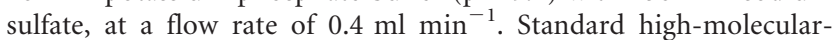
mass proteins were used for calibration, and the molecular mass of native $\mathrm{HpsN}$ was estimated by interpolation in the standard curve. Concentration of protein solutions was done with Vivaspin concentrators (10 kDa cut-off, PES membrane; Sartorius); PD10 columns (Sephadex G-25; GE Healthcare) were used for buffer exchanges.

Bioinformatic procedures. Analysis of the genome sequence of $C$. pinatubonensis JMP134 (accession no. CP000090, chromosome 1; CP000091, chromosome 2; CP000092, megaplasmid; CP000093, plasmid 1) and the draft genome sequence (accession no.
NZ_AALY00000000) of Roseovarius nubinhibens ISM were done using the BLAST algorithm on the National Center for Biotechnology Information website (http://www.ncbi.nlm.nih.gov/). Subroutines from the LASERGENE program package (DNASTAR) were used for handling sequence data, which were in the public domain before 22 December 2009. Primers for (RT-)PCR were designed using the program Amplify (version 1.2).

\section{RESULTS}

\section{DHPS as a sole source of carbon and energy for genome-sequenced bacteria}

We deduced that at least 28 bacteria (Supplementary Table S1), whose genomes have been sequenced, could utilize DHPS via the reactions shown in Fig. 1, and we tested seven representative organisms for growth (Table 1). All organisms were outgrown within 3-8 days, and they released sulfate into the growth medium. The sulfate excretion represented either about $50 \%$ (Ruegeria pomeroyi) or about $100 \%$ recovery of the sulfate concentration expected from complete desulfonation of the DHPS originally present in the growth medium. Each organism was also grown with a non-sulfonated substrate (acetate). In all relevant cases (allowing for growth in clumps), the molar growth yield with DHPS $\left[\mathrm{OD}_{580}(\mathrm{~mol} \mathrm{C})^{-1}\right]$ was about $75-100 \%$ of the control with acetate, except for Ruegeria pomeroyi, where the molar yield with DHPS was half that of the control. The general hypothesis, that HpsNOP were responsible for the reactions in the degradative pathway of DHPS, was still valid.

\section{Desulfonation reactions in different organisms}

We predicted that $C$. pinatubonensis JMP134 would induce SuyAB for the desulfonation in the DHPS pathway (Table 1; Supplementary Table S1). Inducible SuyAB 
Table 1. Growth of representative bacteria with DHPS (or acetate) as sole source of carbon and energy, evaluated as release of sulfate from the sulfonate group and as the growth yield (compared with the control), and the desulfonation reaction(s) potentially available to the organism

\begin{tabular}{|c|c|c|c|c|c|c|}
\hline \multirow[t]{2}{*}{ Organism } & \multirow[t]{2}{*}{$\begin{array}{l}\text { Sulfate formed } \\
\text { (\% of theory) }\end{array}$} & \multicolumn{2}{|c|}{$\begin{array}{l}\text { Molar growth yield } \\
{\left[\mathrm{OD}_{580}(\mathrm{~mol} \mathrm{C})^{-1}\right]}\end{array}$} & \multirow[t]{2}{*}{ Xsc (locus tag/tags) } & \multirow[t]{2}{*}{ CuyA (locus tag) } & \multirow[t]{2}{*}{ Suy(A)B (locus tag) } \\
\hline & & DHPS & Acetate & & & \\
\hline Cupriavidus pinatubonensis JMP134 & 100 & 0.029 & 0.027 & Reut_B3773 & n.o.d. & Reut_C6087 \\
\hline Hoeflea phototrophica DFL-43 & 86 & 0.018 & 0.024 & HPDFL43_18962 & n.o.d. & HPDFL43_17096 \\
\hline Roseobacter denitrificans OCh 114 & 100 & $0.019^{*}$ & 0.024 & RD1_0977/0826 & n.o.d. & n.o.d. \\
\hline Roseobacter sp. strain MED193 & 90 & $0.012^{\star}$ & 0.022 & MED193_12208 & n.o.d. & n.o.d. \\
\hline Roseovarius nubinhibens ISM & 100 & 0.027 & 0.023 & ISM_10690 & ISM_09626 & n.o.d. \\
\hline Roseovarius sp. strain 217 & 84 & 0.020 & 0.019 & ROS217_11936 & ROS217_09350 & n.o.d. \\
\hline Ruegeria pomeroyi DSS-3 & 55 & 0.013 & 0.021 & SPO3561 & SPOA0158 & n.o.d. \\
\hline
\end{tabular}

n.o.d., no orthologue detected.

${ }^{\star}$ Grew in clumps, whereas the acetate control grew in suspended culture.

activity was detected $\left[0.26\right.$ mkat $\left.(\mathrm{kg} \text { protein })^{-1}\right]$ in crude cell extracts. Characteristic for SuyAB is a highly expressed $42 \mathrm{kDa}$ protein band (SDS-PAGE) (SuyB) in induced cells (Denger \& Cook, 2010; Rein et al., 2005), and a peptidemass fingerprint of this band (see below) confirmed its identity as Reut_C6087, as predicted in Table 1.

Similarly, we predicted that Roseovarius nubinhibens ISM would induce both Xsc and CuyA for the desulfonation of DHPS, because this was already known for sulfolactate catabolism (Denger et al., 2009). Inducible activities of Xsc [1.4 mkat $\left.(\mathrm{kg} \text { protein })^{-1}\right]$ and CuyA [0.41 mkat (kg protein $)^{-1}$ ] were observed in crude extracts. Activities of SuyAB (strain JMP134), Xsc and CuyA (strain ISM) were not detectable in extracts of acetate-grown cells.

\section{DHPS dehydrogenases}

Three reactions in the pathway are hypothesized as $\operatorname{NAD}(\mathrm{P})^{+}$-coupled DHPS dehydrogenases (Fig. 1). We could measure an inducible $\mathrm{NAD}^{+}$-coupled DHPS-dehydrogenase activity of 3.2 mkat ( $\mathrm{kg}$ protein $)^{-1}$ in extracts of C. pinatubonensis, and of $0.6 \mathrm{mkat}(\mathrm{kg} \text { protein })^{-1}$ in extracts of Roseovarius nubinhibens. The levels of activity in extracts of non-induced cells were $10 \%$ or less [0.06 mkat $(\mathrm{kg} \text { protein })^{-1}$ in extracts of both strains] of those in induced cells. Activities with $\mathrm{NADP}^{+}$as electron acceptor were detected at lower levels.

Proteins in the soluble fraction of extracts of DHPS-grown cells of $C$. pinatubonensis were separated on an anionexchange column. Three different peaks of DHPS dehydrogenase activity were observed, which eluted at 60, 110 and $120 \mathrm{mM} \mathrm{Na}_{2} \mathrm{SO}_{4}$ in the salt gradient (Fig. 3). The proteins in these active fractions were subject to SDSPAGE, and major relevant protein bands were subject to peptide-mass fingerprinting. The major protein, which eluted at $60 \mathrm{mM} \mathrm{Na}_{2} \mathrm{SO}_{4}$, had a molecular mass of $47 \mathrm{kDa}$, as predicted for $\mathrm{HpsN}$, and this was confirmed by the peptide-mass fingerprint (Reut_C6092); the enzyme was $\mathrm{NAD}^{+}$-linked. Several major protein bands eluted from the anion exchanger at $110 \mathrm{mM} \mathrm{Na}_{2} \mathrm{SO}_{4}$, but the one at $35 \mathrm{kDa}$ was a candidate $\mathrm{HpsP}$, and this was confirmed by the peptide-mass fingerprint (Reut_C6089); the enzyme was $\mathrm{NAD}^{+}$-linked. A major band eluted from the anion exchanger at $120 \mathrm{mM} \mathrm{Na} \mathrm{SO}_{4}$ with a molecular mass of $27 \mathrm{kDa}$, and was thus a candidate $\mathrm{HpsO}$. This was confirmed by the peptide-mass fingerprint (Reut_C6091). The enzyme was $\mathrm{NADP}^{+}$-linked.

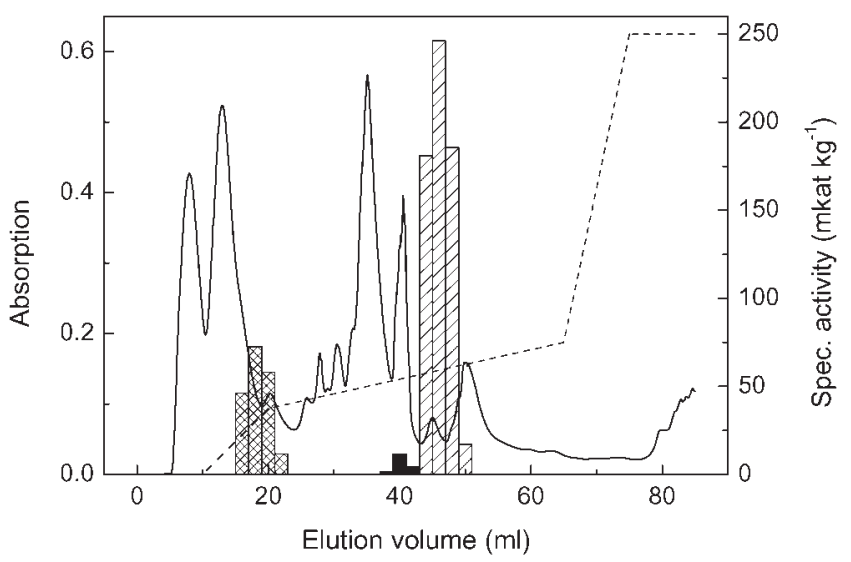

Fig. 3. Separation of DHPS dehydrogenases from C. pinatubonensis JMP134 on an anion-exchange column. Solid line, absorption of eluting protein at $280 \mathrm{~nm}$; dashed line, $\mathrm{Na}_{2} \mathrm{SO}_{4}$ gradient (maximum $=0.5 \mathrm{M}$ ); black bars, specific activity of $\mathrm{NAD}^{+}$-dependent $\mathrm{HpsP}$; checkered bars, specific activity of $\mathrm{NAD}^{+}$-dependent $\mathrm{HpsN}$; striped bars, specific activity of $\mathrm{NADP}^{+}$-dependent $\mathrm{HpsO}$. 


\section{DHPS 3-dehydrogenase}

HpsN, separated from C. pinatubonensis on the anionexchanger column, was purified to near homogeneity (97\%) (Fig. 4) via hydrophobic interaction and gel filtration columns (Table 2). The purification factor of about 29 indicated that $\mathrm{HpsN}$ represented about $3 \%$ of total cell protein (and $5 \%$ of soluble protein), which can be seen clearly in the SDS-PAGE (lane 2 in Fig. 4). The gradual loss of specific activity (and total activity) as the enzyme reached purity indicated a labile enzyme, whose activity was soon lost. The retention time on the calibrated gel filtration column indicated a molecular mass of $75 \mathrm{kDa}$ for the native protein. Compared with the $47 \mathrm{kDa}$ monomer, the data were tentatively interpreted to mean homodimeric HpsN.

HpsN converted DHPS to sulfolactate (Fig. 5). The identity of this product was confirmed by MALDI-TOF-MS in the negative-ion mode. The substrate, DHPS, gave a peak $\left(m / z=155.13=[M-H]^{-1}\right)$, which supported the identity of the compound $\left(M_{\text {calcd }}=156.18\right)$. After addition of enzyme, a product was formed whose signal $\left(m / z=169.13=[M-\mathrm{H}]^{-1}\right)$ confirmed the tentative identification of the product being produced in Fig. 5 as sulfolactate $\left(M_{\text {calcd }}=170.15\right)$.

The $K_{\mathrm{m}}^{\mathrm{app}}\left[V_{\mathrm{max}}\right]$ value for $\mathrm{NAD}^{+}$was $160 \mu \mathrm{M}[95 \mathrm{mkat}(\mathrm{kg}$ protein $\left.)^{-1}\right]$. The $K_{\mathrm{m}}^{\mathrm{app}}$ value for DHPS was $460 \mu \mathrm{M}$. Maximal activity could be detected at $\mathrm{pH}$ values between 9 and 10, above which no measurements were done. The

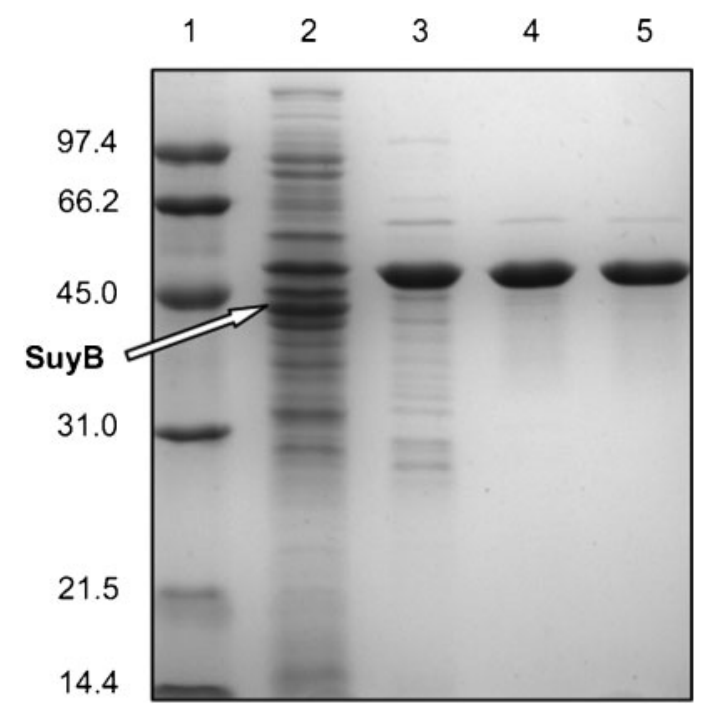

Fig. 4. Electropherogram (SDS-PAGE) of fractions taken during the purification of HpsN from C. pinatubonensis JMP134. Inducible SuyB is marked by the arrow. Lane 1, molecular mass markers $(\mathrm{kDa})$; lane 2, soluble fraction of DHPS-grown cells; lane 3, active fraction after anion-exchange chromatography; lane 4, active fraction after hydrophobic interaction chromatography; lane 5 , purified enzyme $(97 \%)$ after gel filtration chromatography. activity decreased rapidly with decreasing $\mathrm{pH}$; at $\mathrm{pH} 6.5$ the enzyme was almost inactive.

\section{Inducible transcription of hps genes}

HpsNOP were all inducible in C. pinatubonensis (see above). Data from RT-PCR experiments (Fig. 6) showed that not only $h p s N O P$ but also $h p s U$ were transcribed inducibly. As these four genes ( $h p s N O U P$ ) are contiguous, the transcription of all four is unsurprising.

The enzymic data showed that HpsNOP were inducible in Roseovarius nubinhibens. RT-PCR experiments showed no transcription $(h p s N P)$ or weak transcription $(h p s O)$ in acetate-grown cells, whereas DHPS-grown cells showed strong transcription of $h p s N O P$. This was consistent with the enzymic data. In contrast, the putative transporter genes $(h p s K L M)$ were apparently constitutively transcribed, whereby $h p s M$ gave a strong signal and $h p s K L$ gave weak ones. In contrast to C. pinatubonensis, the transporter genes are encoded at a distance from $h p s R N O P$, so a difference in regulation of the two clusters is possible.

\section{DISCUSSION}

A wide range of three-carbon sulfonates $\left(\mathrm{C}_{3}\right.$-sulfonates $)$ has been observed to derive from sulfoquinovose (e.g. Roy et al., 2003; Shibuya et al., 1963), and these $C_{3}$ compounds are often interconvertible (e.g. Cook et al., 2006; Weinstein \& Griffith, 1988). However, only (S)-cysteate seems to be readily available commercially, and other compounds have to be synthesized by the researcher, often with great difficulty. Our attempts to synthesize DHPS as published (Roy et al., 2003) gave a $6 \%$ yield after a week, so the overnight production of the barium bispropane-2,3diolsulfonate in the $100 \mathrm{~g}$ scale, and later the sodium salt, allowed us to do the present work comfortably. The general method might be old-fashioned (Friese, 1938) but it generates a high yield of high-quality product (Fig. 2).

DHPS, known to be widespread (see Introduction), is degraded by bacteria from marine and terrestrial habitats (Table 1), representative of a much larger group of organisms (Supplementary Table S1). All of these 28 organisms (Supplementary Table S1) share hpsNOP, from which we hypothesized their ability to degrade DHPS. Most of them encode the putative transcriptional regulator, HpsR (Supplementary Table S1). The degradative organisms employ three different desulfonation reactions (Table 1), which suffice for the whole group of organisms (Supplementary Table S1). The data indicate at least four different transporters. C. pinatubonensis transcribes an MFS-type transport system (Supplementary Table S1), which we find to be rare in BLAST analyses, in that the nearest orthologues ( $<67 \%$ identity) are IseU, responsible for isethionate uptake (Weinitschke et al., 2010). The most common putative transporter is HpsKLM, but many organisms have no hpsKLM genes (Supplementary Table S1). 
Table 2. Purification table for the $\mathrm{NAD}^{+}$-dependent DHPS dehydrogenase HpsN from C. pinatubonensis JMP134

\begin{tabular}{|lccccc|}
\hline Purification step & Protein $(\mathbf{m g})$ & $\begin{array}{c}\text { Specific activity } \\
\left.(\mathbf{m k a t ~ k g})^{-\mathbf{1}}\right)\end{array}$ & $\begin{array}{c}\text { Activity } \\
\left(\mathbf{n m o l ~ s}^{-\mathbf{1}}\right)\end{array}$ & $\begin{array}{c}\text { Yield (\%) } \\
\text { Purification } \\
(-\mathbf{f o l d})\end{array}$ \\
\hline Crude extract & 30 & 3.2 & 96 & 100 & 1 \\
Soluble fraction & 25 & 4.9 & 123 & 128 & 1.5 \\
Anion-exchange chromatography & 1.3 & 93 & 121 & 126 & 29 \\
Hydrophobic interaction chromatography & 0.11 & 84 & 9.2 & 10 \\
Gel filtration chromatography & 0.02 & 79 & 1.6 & 26 \\
\end{tabular}

However, a representative of this group, Roseobacter denitrificans, grows well with DHPS (Table 1), so an unknown transporter must be present. Further, the fact that Ruegeria pomeroyi degrades DHPS to only $50 \%$ (Table 1) might imply that only one, enantiomer-specific DHPS-transporter is present (HpsKLM), and that this and other organisms have another, unknown transporter. Finally, Verminephrobacter eiseniae potentially encodes a fourcomponent $\mathrm{ABC}$-type transporter $\left(\mathrm{Hps}_{\mathrm{ABB}} \mathrm{C} \mathrm{C}\right)$ adjacent to $h p s R$ and $h p s N O P$ (Supplementary Table S1). Thus, with several transporters and desulfonation mechanisms (Table 1), there is considerable biodiversity in DHPS degradation.

The enzymes HpsNOP are often annotated in databases as 'histidinol dehydrogenase', 'gluconate 5-dehydrogenase' and 'L-threonine 3-dehydrogenase', respectively (e.g. in $C$. pinatubonensis JMP134). While these names are somewhat misleading, they indicate that two enzymes could oxidize a secondary alcohol, whereas one oxidizes a primary alcohol. We thus predicted that $\mathrm{HpsN}$ would oxidize the primary alcohol of one enantiomer of DHPS, presumably $(R)$ DHPS, to generate $(R)$-sulfolactate, the recently recognized enantiomer that is the substrate for SuyAB (Denger \& Cook, 2010). And HpsN does, indeed, generate sulfolactate, presumably $(R)$-sulfolactate, from DHPS (Fig. 5) in an $\mathrm{NAD}^{+}$-coupled reaction. Both $\mathrm{HpsO}\left(\mathrm{NADP}^{+}{ }^{-}\right.$-coupled $)$

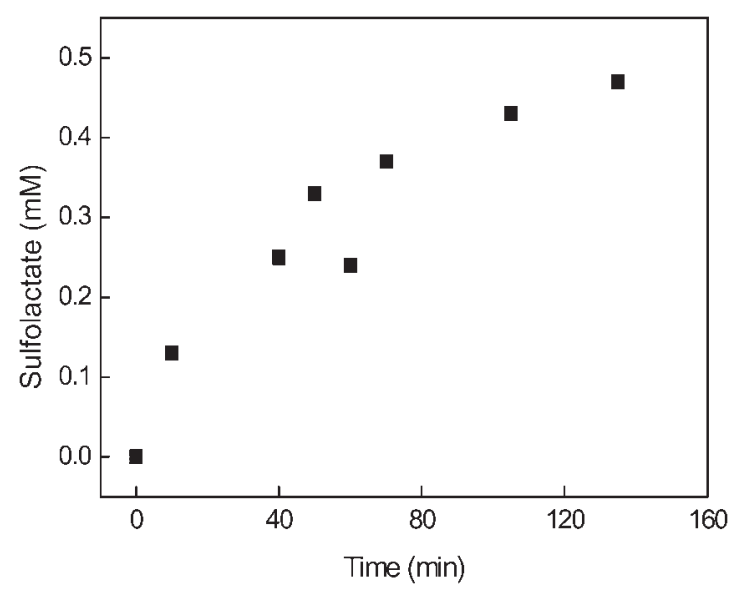

Fig. 5. Formation of sulfolactate from DHPS by $\mathrm{HpsN}$ from $\mathrm{C}$. pinatubonensis JMP134. No sulfolactate was formed in control experiments without DHPS or with heat-inactivated protein. and HpsP ( $\mathrm{NAD}^{+}$-coupled) oxidize DHPS (Fig. 3), presumably at the secondary alcohol (see above), and presumably with opposite enantiomers of DHPS to effect a racemase reaction. This is analogous to the effective sulfolactate racemase catalysed by two dehydrogenases in many organisms (Denger \& Cook, 2010). Given that HpsP is annotated to act on $(2 S, 3 R)$-threonine, whereby the hydroxyl group at the $\mathrm{C} 3$ position has the $(R)$ configuration, we tentatively suggest that HpsP is $(R)$ DHPS 2-dehydrogenase and that HpsO is (S)-DHPS 2-dehydrogenase.

We thus deduce that HpsN catalyses the $\mathrm{NAD}^{+}$-coupled oxidation of $(R)$-DHPS to $(R)$-sulfolactate and that this enzyme should have the systematic name $(R)-2,3$ dihydroxypropanesulfonate: $\mathrm{NAD}^{+}$3-oxidoreductase [EC 1.1.1.-]. The corresponding accepted name could be sulfopropanediol 3-dehydrogenase. Similarly, if the deductions are correct, $\mathrm{HpsO}$ would be $(S)$-sulfopropanediol 2-dehydrogenase and HpsP would be $(R)$-sulfopropanediol 2-dehydrogenase.

Roy et al. (2003) established that SQ can be degraded via sulfoglycolysis (and/or equivalent pathways) to DHPS by the bacterium Klebsiella sp. strain ABR11, which is a poor degrader of DHPS, and which excretes it quantitatively. We hypothesize that an organism like C. pinatubonensis JMP134 would degrade this DHPS by the pathway in Fig. 1. In the marine environment, diatoms and algae generate DHPS from SQ (e.g. Shibuya et al., 1963), and we presume that members of the widespread Roseobacter clade can degrade the compound, as do Roseovarius nubinhibens ISM and Ruegeria pomeroyi DSS-3 (Table 1). We know neither the role of excreted DHPS nor the amounts or fluxes of the compound. Perhaps HpsN could be used to quantify DHPS in native environments.

\section{ACKNOWLEDGEMENTS}

We are grateful to T. Brinkhoff (University of Oldenburg, Germany) for Roseobacter denitrificans OCh 114, M. A. Moran (University of Georgia, Athens, USA) for Roseovarius nubinhibens ISM and Ruegeria pomeroyi DSS-3, J. C. Murrell (University of Warwick, UK) for Roseovarius sp. strain 217, and J. Pinhassi for Roseobacter sp. strain MED193. The project was funded by the Zukunftskolleg der Universität Konstanz (J.M.), the DFG (J.M.) (to T. H. M. Smits and A.M.C.) under the auspices of the Research School Chemical Biology, and the University of Konstanz. 


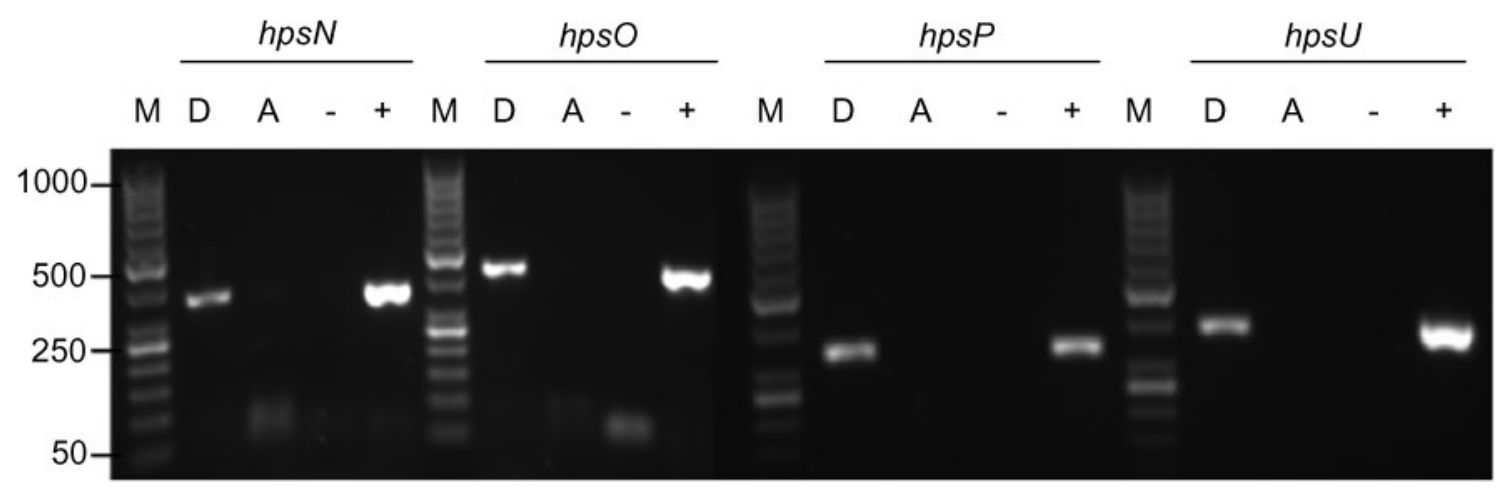

Fig. 6. Representative agarose gels from RT-PCR experiments: transcripts of hpsNOPU from C. pinatubonensis JMP134. M, molecular markers (bp); D, RT-PCR with RNA isolated from DHPS-grown cells; A, RT-PCR with RNA isolated from acetategrown cells; -, negative control omitting template; + , positive control with genomic DNA.

\section{REFERENCES}

Benson, A. A. (1963). The plant sulfolipid. Adv Lipid Res 1, 387-394. Benson, A. A. \& Lee, R. F. (1972). The sulphoglycolytic pathway in plants. Biochem J 128, 29P-30P.

Benson, A. A. \& Shibuya, I. (1961). Sulfocarbohydrate metabolism. Fed Proc 20, 79.

Biebl, H., Tindall, B. J., Pukall, R., Lunsdorf, H., Allgaier, M. \& Wagner-Dobler, I. (2006). Hoeflea phototrophica sp. nov., a novel marine aerobic alphaproteobacterium that forms bacteriochlorophyll a. Int J Syst Evol Microbiol 56, 821-826.

Busby, W. F. (1966). Sulfopropanedial and cysteinolic acid in the diatom. Biochim Biophys Acta 121, 160-161.

Cook, A. M., Denger, K. \& Smits, T. H. M. (2006). Dissimilation of $\mathrm{C}_{3^{-}}$ sulfonates. Arch Microbiol 185, 83-90.

Denger, K. \& Cook, A. M. (2010). Racemase activity effected by two dehydrogenases in sulfolactate degradation by Chromohalobacter salexigens: purification of $(S)$-sulfolactate dehydrogenase. Microbiology 156, 967-974.

Denger, K., Ruff, J., Rein, U. \& Cook, A. M. (2001). Sulfoacetaldehyde sulfo-lyase [EC 4.4.1.12] from Desulfonispora thiosulfatigenes: purification, properties and primary sequence. Biochem $J$ 357, 581586.

Denger, K., Weinitschke, S., Hollemeyer, K. \& Cook, A. M. (2004). Sulfoacetate generated by Rhodopseudomonas palustris from taurine. Arch Microbiol 182, 254-258.

Denger, K., Smits, T. H. M. \& Cook, A. M. (2006). L-Cysteate sulfolyase, a widespread, pyridoxal $5^{\prime}$-phosphate-coupled desulfonative enzyme purified from Silicibacter pomeroyi DSS- $3^{\mathrm{T}}$. Biochem J 394, 657-664.

Denger, K., Mayer, J., Buhmann, M., Weinitschke, S., Smits, T. H. M. \& Cook, A. M. (2009). Bifurcated degradative pathway of 3-sulfolactate in Roseovarius nubinhibens ISM via sulfoacetaldehyde acetyltransferase and (S)-cysteate sulfo-lyase. J Bacteriol 191, 5648-5656.

Desomer, J., Crespi, M. \& Van Montagu, M. (1991). Illegitimate integration of non-replicative vectors in the genome of Rhodococcus fascians upon electrotransformation as an insertional mutagenesis system. Mol Microbiol 5, 2115-2124.

Ellis, K. J. \& Morrison, J. F. (1982). Buffers of constant ionic strength for studying pH-dependent processes. Methods Enzymol 87, 405426.
Friese, H. (1938). Über die Reaktion von Schwefelsäure mit ungesättigten Verbindungen (X. Mitteil. über Lignin). Berichte der Deutschen Chemischen Gesellschaft 71, 1303-1306.

González, J. M., Covert, J. S., Whitman, W. B., Henriksen, J. R., Mayer, F., Scharf, B., Schmitt, R., Buchan, A., Fuhrman, J. A. \& other authors (2003). Silicibacter pomeroyi sp. nov. and Roseovarius nubinhibens sp. nov., dimethylsulfoniopropionate-demethylating bacteria from marine environments. Int J Syst Evol Microbiol 53, 1261-1269.

Krejčík, Z., Denger, K., Weinitschke, S., Hollemeyer, K., Pačes, V., Cook, A. M. \& Smits, T. H. M. (2008). Sulfoacetate released during the assimilation of taurine-nitrogen by Neptuniibacter caesariensis: purification of sulfoacetaldehyde dehydrogenase. Arch Microbiol 190, 159-168.

Laemmli, U. K. (1970). Cleavage of structural proteins during the assembly of the head of bacteriophage T4. Nature 227, 680-685.

Lee, R. F. \& Benson, A. A. (1972). The metabolism of glyceryl $\left[{ }^{35} \mathrm{~S}\right]$ sulfoquinovoside by the coral tree, Erythrina crista-galli, and alfalfa, Medicago sativa. Biochim Biophys Acta 261, 35-37.

Mayer, J. \& Cook, A. M. (2009). Homotaurine metabolized to 3sulfopropanoate in Cupriavidus necator H16: enzymes and genes in a patchwork pathway. J Bacteriol 191, 6052-6058.

Pfennig, N. (1978). Rhodocyclus purpureus gen. nov. sp. nov., a ring-shaped, vitamin $B_{12}$-requiring member of the family Rhodospirillaceae. Int J Syst Bacteriol 28, 283-288.

Racker, E. (1962). Fructose-6-phosphate phosphoketolase from Acetobacter xylinum. Methods Enzymol 5, 276-280.

Rein, U., Gueta, R., Denger, K., Ruff, J., Hollemeyer, K. \& Cook, A. M. (2005). Dissimilation of cysteate via 3-sulfolactate sulfo-lyase and a sulfate exporter in Paracoccus pantotrophus NKNCYSA. Microbiology 151, 737-747.

Roy, A. B., Hewlins, M. J. E., Ellis, A. J., Harwood, J. L. \& White, G. F. (2003). Glycolytic breakdown of sulfoquinovose in bacteria: a missing link in the sulfur cycle. Appl Environ Microbiol 69, 6434-6441.

Ruff, J., Denger, K. \& Cook, A. M. (2003). Sulphoacetaldehyde acetyltransferase yields acetyl phosphate: purification from Alcaligenes defragrans and gene clusters in taurine degradation. Biochem J 369, 275-285.

Schäfer, H., McDonald, I. R., Nightingale, P. D. \& Murrell, J. C. (2005). Evidence for the presence of a CmuA methyltransferase pathway in novel marine methyl halide-oxidizing bacteria. Environ Microbiol 7, 839-852. 
Shiba, T. (1991). Roseobacter litoralis gen. nov., sp. nov., and Roseobacter denitrificans sp. nov., aerobic pink-pigmented bacteria which contain bacteriochlorophyll a. Syst Appl Microbiol 14, 140-145.

Shibuya, I., Yagi, T. \& Benson, A. A. (1963). Sulfonic acids in algae. In Studies on Microalgae and Photosynthetic Bacteria, pp. 627-636. Edited by Japanese Society of Plant Physiologists. Tokyo: University of Tokyo Press.

Sörbo, B. (1987). Sulfate: turbidimetric and nephelometric methods. Methods Enzymol 143, 3-6.

Tholey, A., Wittmann, C., Kang, M. J., Bungert, D., Hollemeyer, K. \& Heinzle, E. (2002). Derivatization of small biomolecules for optimized matrix-assisted laser desorption/ionization mass spectrometry. J Mass Spectrom 37, 963-973.
Thurnheer, T., Köhler, T., Cook, A. M. \& Leisinger, T. (1986). Orthanilic acid and analogues as carbon sources for bacteria: growth physiology and enzymic desulphonation. J Gen Microbiol 132, 12151220.

Weinitschke, S., Sharma, P. I., Stingl, U., Cook, A. M. \& Smits, T. H. M. (2010). Gene clusters involved in isethionate degradation in terrestrial and marine bacteria. Appl Environ Microbiol 76, 618-621.

Weinstein, C. L. \& Griffith, O. W. (1988). Cysteinesulfonate and $\beta$ sulfopyruvate metabolism. Partitioning between decarboxylation, transamination, and reduction pathways. J Biol Chem 263, 37353743 .

Edited by: M. A. Kertesz 